\title{
FOUR NEW SPECIES OF HETERANTHOCIDIUM (ORCHIDACEAE) FROM COLOMBIA AND SURINAME
}

\author{
Dariusz L. SzlachetKo, Natalia Olędrzyńska \& Marta Kolanowska ${ }^{1}$
}

\begin{abstract}
Four new species of Heteranthocidium Szlach., Mytnik \& Romowicz are described and illustrated. Each morphological description is complemented with data on the species' ecology and distribution. The taxonomic affinities of the novelties are briefly discussed.
\end{abstract}

Key words: biodiversity, distribution, Neotropics, Oncidiinae sect. Heterantha, taxonomy

Dariusz L. Szlachetko, Natalia Olędrzyńska \& Marta Kolanowska, Department of Plant Taxonomy and Nature Conservation, University of Gdańsk, Wita Stwosza 59,80-308 Gdańsk, Poland; e-mail: martakolanowska@wp.pl

\section{INTRODUCTION}

The Neotropical genus Oncidium Sw. is one of the most controversial orchid taxa within Orchidaceae. Since its description (Swartz 1800), ca 1200 specific names have published in this genus. The discussion on the infrageneric classification of Oncidium began in the mid- $19^{\text {th }}$ century when Lindley (1842) demarcated two sections: $O$. sect. Cebolletae and $O$. sect. Ranifera. Both were later elevated to generic rank, as Cohniella Pfitzer and Menezesiella Chiron \& V. P. Castro respectively. In subsequent research (e.g., Lindley \& Paxton 1850 1851; Lindley 1855; Kraenzlin 1922), scientists established ca 50 new sections within Oncidium. The new infrageneric taxa were created based on the pseudobulb form, leaf shape, connation of the tepals, and lip morphology.

Among the numerous species groups recognized within Oncidium, only one produces dimorphic flowers. Those plants were first highlighted by Lindley as the separated $O$. sect. Plurituberculata-hymenoptera-heterantha (Lindley 1855); the author included only three species: $O$. cultratum Lindl., O. pentadactylon Lindl. and O. retusum Lindl. Later the autonomous section Heterantha was proposed by Kraenzlin (1922) to accommo-

\footnotetext{
1 Corresponding author
}

date 28 Oncidium species with dimorphic flowers. More recently this section was elevated to generic rank by Szlachetko et al. (2006) and named $\mathrm{He}$ teranthocidium in reference to the heteranthous inflorescence; they initially included 15 species but in the most recent studies (Szlachetko \& Kolanowska 2015) a total of 34 species were recognized within the genus. Representatives of Heteranthocidium produce ellipsoid to ovoid, flattened, uni- or bifoliate pseudobulbs which are partially enclosed at the base by longitudinally folded sheaths on each side. The leaf is thin, and linear to obovate. The lateral inflorescence of those plants is paniculate, composed of numerous resupinate flowers. Fertile flowers are larger than the sterile ones. Sterile flowers are often stellate. The ovary is glabrous and the tepals are free, subsimilar and usually spreading. The sessile lip is entire or 3-lobed, ornamented with a prominent callus. The gynostemium is short, rather massive, distinctly swollen above a delicate and narrow base, with the column part as long as the anther or slightly longer, and broadly winged near the stigma. The wings are obliquely subquadrate to obovate, sometimes bipartite, irregularly denticulate and/or papillate along the margins. No column foot is produced. The ventral anther is incumbent, 
operculate, oblong ovoid, dorsiventrally flattened, obscurely 2-chambered and papillate. The connective is narrow, slightly thickened on the dorsal surface. Two subglobose, dorsiventrally flattened, hard pollinia are produced. The caudiculae are sticky and amorphous. The apical clinandrium is narrow, and the elliptic stigma is rather large and deeply concave. The elongate rostellum is conicaldigitate and its remnant is bilobulate in the middle. The single viscidium is very small, oblong to elliptic, thick and fleshy. The single, thin, lamellate tegula is oblong-obovate to oblong-triangular, elongate at the apex and slightly thickened there (Szlachetko \& Mytnik-Ejsmont 2009).

The geographical range of Heteranthocidium extends from Costa Rica to Bolivia and Brazil. Plants are usually found growing epiphytically in premontane and montane areas, but $H$. pentadactylon was found at higher elevations at $c a$ $3500 \mathrm{~m}$ a.s.1. (Senghas 1997).

During recent studies of oncidioid orchids in the Missouri Botanical Garden, four distinctive representatives of Heteranthocidium were found. They are described and illustrated as new species here.

\section{TAXONOMIC TREATMENT}

Heteranthocidium ciliicolumna Szlach. \& Kolan., sp. nov.

Fig. 1

Species similar to $H$. pentadactylon (Senghas) Szlach. \& Kolan., distinguished by the distinctly spathulate lateral sepals, semicircular lip lateral lobes, obliquely elliptic lip middle lobe lobules, and callus consisting of three central rows of protuberances and additional small protuberances on each lip lateral lobe.

HolotyPe: COLOMBIA. Antioquia. Fonnegra \& al. 3210 (MO).

Pseudobulbs up to $3 \mathrm{~cm}$ tall and $0.8 \mathrm{~cm}$ in diameter, ellipsoid, compressed. Leaf absent. Inflorescence $30-40 \mathrm{~cm}$ long, laxly many-flowered, with some branches, branches up to $5 \mathrm{~cm}$ long, usually with 1 terminal fertile flower and several sterile flowers below. Sterile flowers stellate, segments ca $2 \mathrm{~mm}$ long, linear. Fertile flowers - floral

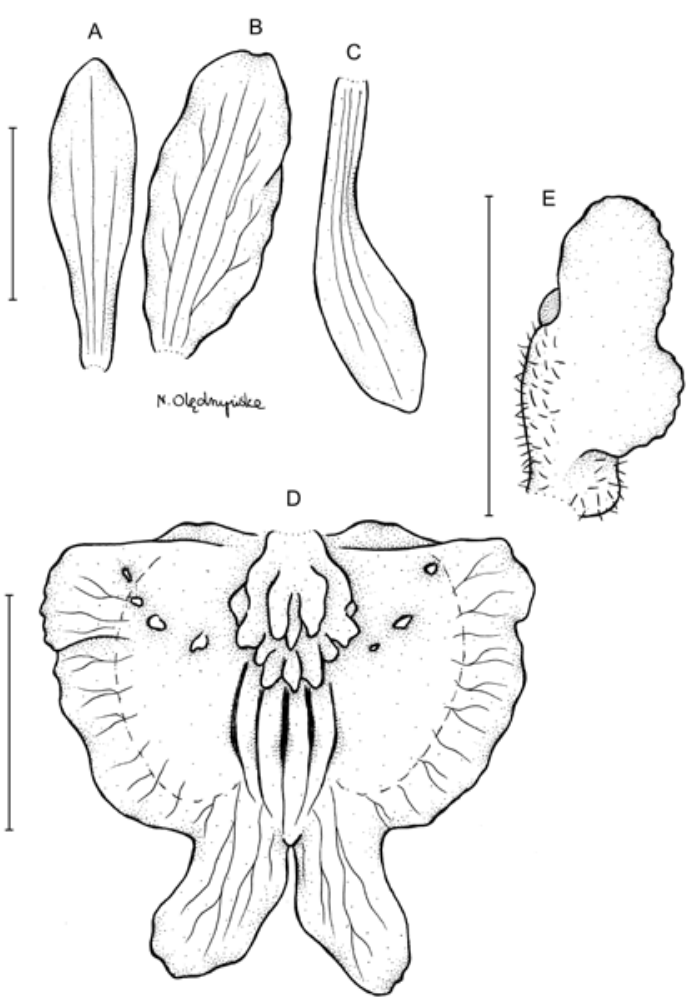

Fig. 1. Heteranthocidium ciliicolumna Szlach. \& Kolan., sp. nov. A - dorsal sepal, B - petal, C - lateral sepal, D - lip, E gynostemium. Scale bar $=5 \mathrm{~mm}$. Drawn by N. Olędrzyńska from the holotype.

bracts $1.5 \mathrm{~mm}$ long, triangular-ovate, acute. Pedicellate ovary $12 \mathrm{~mm}$ long, slender. Dorsal sepal $9.5 \mathrm{~mm}$ long, $2 \mathrm{~mm}$ wide, ligulate-spatulate, rounded at apex. Petals $9 \mathrm{~mm}$ long, $4 \mathrm{~mm}$ wide, sessile, obliquely elliptic, apically truncate to emarginate. Lateral sepals $9 \mathrm{~mm}$ long, $2.1 \mathrm{~mm}$ wide, claw linear, blade oblong, subobtuse, oblique. Lip 10-11 mm long and wide, sessile, base truncate, subreniform in outline, papillate in center, margins erose, somewhat undulate, lip middle lobe deeply bilobulate, lobules obliquely elliptic, basal callus glabrous, large, composed of several ridges and projections, with 5 keels running to the bottom of the sinus between the lobules and additional knob-like projections on each side of the main callus. Gynostemium $6 \mathrm{~mm}$ long, densely ciliate, staminodes bilobed, margins irregularly crenulate, apex rounded. 


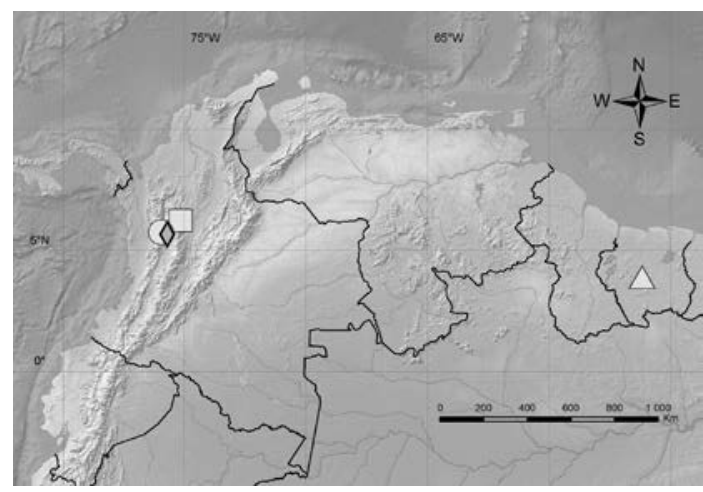

Fig. 2. Localities of Heteranthocidium ciliicolumna Szlach. \& Kolan., sp. nov. $(\diamond), H$. mandritum Szlach. \& Kolan., sp. nov. $(\square)$, H. surinamensis Szlach. \& Kolan., sp. nov. $(\triangle)$, and H. croatii Szlach. \& Kolan., sp. nov. (○).

ETYMOLOGY. In reference to the densely ciliate gynostemium.

HABITAT AND ECOLOGY. Growing epiphytically in humid forest $c a 5 \mathrm{~m}$ above the ground. Flowering in February.

Distribution. Known exclusively from the Colombian Central Andean Cordillera, where it was found growing at $c a 1850 \mathrm{~m}$ a.s.l. (Fig. 2).

REPRESENTATIVE SPECIMEN: COLOMBIA. Antioquia: Mpio. Támesis. Vereda Río Frío, Alt. 2100 m, 9 Nov. 1989, R. Fonnegra, F. Roldan, B. Corral \& M. Giron 3210 (MO).

Notes. Species similar to $H$. pentadactylon, distinguished by the distinctly spathulate lateral sepals, semicircular lip lateral lobes, obliquely elliptic lip middle lobe lobules, and callus consisting of three central rows of protuberances and additional small protuberances on each lip lateral lobe.

From H. tigratum (Rchb. f. \& Warsz.) Szlach., Mytnik \& Romowicz it differs by the short lip isthmus, larger lip lateral lobes and glabrous lip callus, and from H. magnificum (Senghas) Szlach. \& Kolan. by the complex callus and larger lip middle lobe lobules.

Heteranthocidium mandritum Szlach. \& Kolan., sp. nov.

Fig. 3

Species resembling $H$. heterodactylum (Kraenzl.) Szlach. \& Kolan., from which it differs in callus structure, which is many-toothed in the basal third of the lip, and the additional row of small protuberances present on both lip lateral lobes.

Holotype: COLOMBIA. Antioquia. de Escobar \& al. $6320(\mathrm{MO})$.

Pseudobulbs up to $2.5 \mathrm{~cm}$ tall and $0.6 \mathrm{~cm}$ in diameter, oblongoid-ellipsoid, compressed, 1-leaved, concealed basally by leafy sheaths. Leaf shortly petiolate; petiole $\mathrm{ca} 1 \mathrm{~cm}$ long; blade up to $7.5 \mathrm{~cm}$ long and $1 \mathrm{~cm}$ wide, lanceolate, subacute. Inflorescence $40 \mathrm{~cm}$ long, laxly many-flowered, branching, branches up to $4 \mathrm{~cm}$ long, usually with 1 terminal fertile flower and several sterile flowers below. Sterile flowers stellate, segments $c a 2 \mathrm{~mm}$ long, linear. Fertile flowers - floral bracts $3 \mathrm{~mm}$ long, triangular-ovate, acute. Pedicellate ovary $8 \mathrm{~mm}$ long, slender. Dorsal sepal $9 \mathrm{~mm}$ long, $2.3 \mathrm{~mm}$
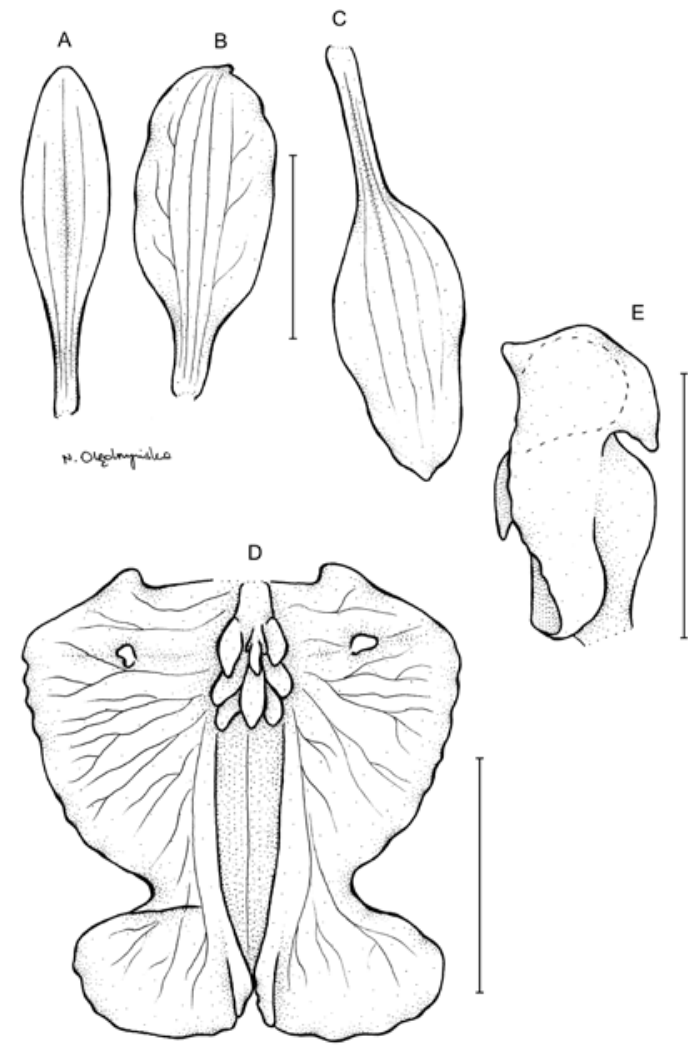

Fig. 3. Heteranthocidium mandritum Szlach. \& Kolan., sp. nov. A - dorsal sepal, B - petal, C - lateral sepal, D - lip, E gynostemium. Scale bar $=5 \mathrm{~mm}$. Drawn by N. Olędrzyńska from the holotype. 
wide, claw linear, blade elliptic-ligulate, rounded at apex. Petals $9.5 \mathrm{~mm}$ long, $4 \mathrm{~mm}$ wide, basally shortly clawed, elliptic, apically obtuse, somewhat oblique. Lateral sepals $9 \mathrm{~mm}$ long, $2.5 \mathrm{~mm}$ wide, claw linear, blade oblong ovate, obtuse, oblique. Lip 9-10 mm long, $7.5 \mathrm{~mm}$ wide, sessile, truncate at base, semiorbicular in outline, margins entire, somewhat undulate, lip middle lobe transversely ligulate, sinus shallow, basal callus rather small, composed of 3 rows of 3 parallel ridges, glabrous, with single knob-like projection on each side. Gynostemium $5 \mathrm{~mm}$ long, glabrous, staminodes large and spacious, with basal pocket-like cavities, apical part of staminodes cowl-like.

ETymology. Mandrita (Lat.) - monk, an allusion to the form of the gynostemium seen from the side.

HABITAT AND ECOLOGY. Epiphytic plant growing in humid forest. Flowering in November.

Distribution. Known exclusively from the Colombian Western Andean Cordillera, where it was found growing at ca $2100 \mathrm{~m}$ a.s.l. (Fig. 2).

REPRESENTATIVE SPECIMEN: COLOMBIA. Antioquia: Mpio. Guatape. Vereda Santa Rita. Bosque humedo, Alt. 1850 m, 27 Feb. 1986, L. De Escobar, A. Uribe, J. Vallejo \& F. Roldan 6320 (MO). Fig. 2.

Notes. Species resembling $H$. heterodactylum, from which it differs in callus structure, which is many-toothed in the basal third of the lip, and the additional row of small protuberances present on both lip lateral lobes.

It is also similar to $H$. silvanoi, but with a series of small protuberances on both lip lateral lobes, obliquely ovate, rather narrow lobules of the lip middle lobe, and apically rounded gynostemium wings with denticulate margins.

Heteranthocidium surinamensis Szlach. \& Kolan., sp. nov.

Fig. 4

Species distinguished by the unlobed, subrectangular lip and dolabriform, undulate petals.

HolotyPe: SURINAME. Evans \& al. 3083 (MO).

Pseudobulbs $3.5 \mathrm{~cm}$ tall, $1 \mathrm{~cm}$ in diameter, ovoid-oblongoid, compressed, 1-leaved. Leaf shortly petiolate; petiole $c a 1.5 \mathrm{~cm}$ long; blade $8 \mathrm{~cm}$ long, $1 \mathrm{~cm}$ wide, oblong-lanceolate, acute. Inflorescence $80 \mathrm{~cm}$ long, laxly many-flowered, heavily branching, branches up to $7 \mathrm{~cm}$ long, usually with 1 terminal fertile flower and several sterile flowers below. Sterile flowers stellate, segments ca $3 \mathrm{~mm}$ long, linear. Fertile flowers - floral bracts $1 \mathrm{~mm}$ long, obscure, triangular-ovate, acute. Pedicellate ovary $12 \mathrm{~mm}$ long, slender. Dorsal sepal $5 \mathrm{~mm}$ long, $2 \mathrm{~mm}$ wide, basally shortly clawed, oblongovate above, rounded at apex. Petals $5.5 \mathrm{~mm}$ long, $4 \mathrm{~mm}$ wide, obliquely dolabriform, subacute to subobtuse, outer margin erose. Lateral sepals $6 \mathrm{~mm}$ long, $2 \mathrm{~mm}$ wide, oblong-elliptic above linear claw, oblique, acute. Lip $10 \mathrm{~mm}$ long, 8-9 mm wide, subrectangular in outline, sessile, deeply notched at apex, margins irregularly crenulate, basal callus a relatively small, flat pad surrounded by narrow rim, apically 3-dentate, gradually transforming into 3 keels running along basal part of nerves. Gynostemium $4.5 \mathrm{~mm}$ long, glabrous, staminodes widely spread, very large, dolabriform, with erose margins, apex rounded.

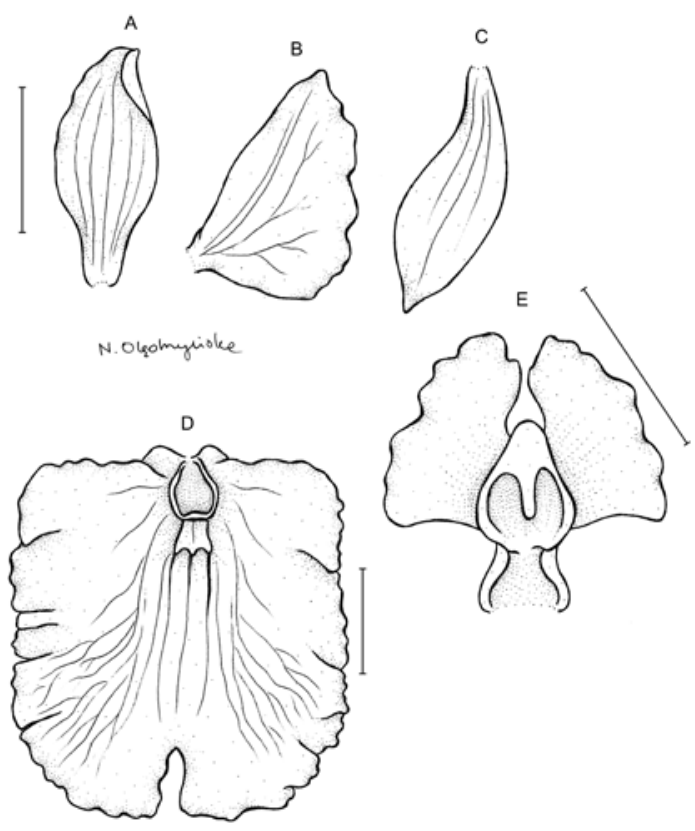

Fig. 4. Heteranthocidium surinamensis Szlach. \& Kolan., sp. nov. A - dorsal sepal, B - petal, C - lateral sepal, D - lip, E gynostemium. Scale bar $=3 \mathrm{~mm}$. Drawn by N. Olędrzyńska from the holotype. 
ETYMOLOGY. In reference to the country of origin of the new species.

HABITAT AND ECOLOGY. Epiphytic plant growing in primary wet forest $2-6 \mathrm{~m}$ above the ground. Flowering in July.

Distribution. Known exclusively from the Guiana Highlands, where it was found growing at $c a 725 \mathrm{~m}$ a.s.l. (Fig. 2).

REPRESENTATIVE SPECIMEN: SURINAME. Sipaliwini. Summit of Tafelberg. SW rim of Arrowhead Basin, $c a$ $4 \mathrm{~km}$ from Lisa Creek waterfall over $\mathrm{W}$ rim of tepui, $3^{\circ} 54^{\prime} 20^{\prime \prime} \mathrm{N} 56^{\circ} 10^{\prime} 30^{\prime \prime} \mathrm{W}$, Alt. $725 \mathrm{~m}$, 5 Jul. 1998, R. Evans, H. Peckham \& L. Lohmann 3083 (MO).

Notes. Heteranthocidium surinamensis is similar to $H$. colombianum Szlach. \& Kolan. in lip shape, but may be distinguished from the latter by lip callus form (apically 3-dentate, gradually transforming into 3 keels, vs 3 knob-like projections), petal shape (dolabriform vs ligulate) and staminode position (broadly spread vs touching each other in front of anther).

Heteranthocidium croatii Szlach. \& Kolan., sp. nov.

Fig. 5

Species similar to H. adelaidae (Koniger) Szlach., but with a glabrous callus consisting of five rows of digitate projections. It also resembles H. rostrans (Rchb.f.) Szlach. \& Kolan., but this species produces smaller flowers with a lip lacking protuberances on the lateral lobes, and its gynostemium wings are bilobed.

Holotype: COLOMBIA. Valle del Cauca: Croat 70734 (MO).

Pseudobulbs up to $4.5 \mathrm{~cm}$ tall and $1.3 \mathrm{~cm}$ in diameter, ellipsoid, compressed, 1-leaved, concealed basally by large, leafy sheaths. Leaf shortly petiolate; petiole $c a 1.5 \mathrm{~cm}$ long; blade up to $11 \mathrm{~cm}$ long and $3.3 \mathrm{~cm}$ wide, elliptic-ligulate, rounded at apex. Inflorescence $30 \mathrm{~cm}$ long, laxly many-flowered, with few branches, which are secondarily branched, branches up to $5 \mathrm{~cm}$ long, usually with 1-2 terminal, fertile flowers and several sterile flowers below. Sterile flowers stellate, segments $c a$ 2-3 mm long, linear. Fertile flowers - floral bracts $0.5 \mathrm{~mm}$ long, obscure,
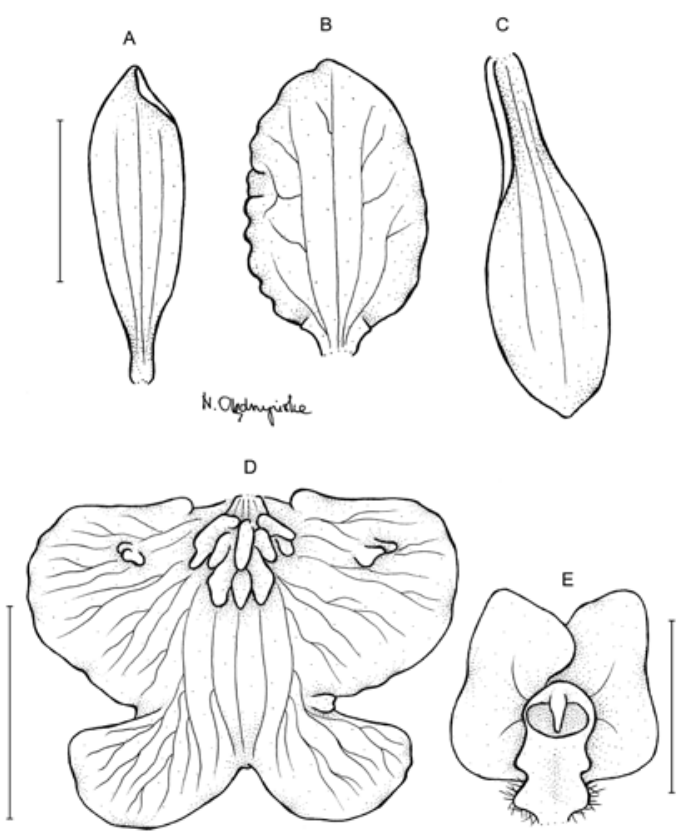

Fig. 5. Heteranthocidium croatii Szlach. \& Kolan., sp. nov. A - dorsal sepal, B - petal, C - lateral sepal, D - lip, E gynostemium. Scale bars $=5 \mathrm{~mm}$. Drawn by N. Olędrzyńska from the holotype.

triangular-ovate, acute. Pedicellate ovary $19 \mathrm{~mm}$ long, slender. Dorsal sepal $10 \mathrm{~mm}$ long, $2 \mathrm{~mm}$ wide, shortly clawed, blade ligulate to ligulateobovate, obtuse. Petals $9 \mathrm{~mm}$ long, $5 \mathrm{~mm}$ wide, sessile, suborbicular, obtuse, margins somewhat undulate. Lateral sepals $9 \mathrm{~mm}$ long, $2.5 \mathrm{~mm}$ wide, claw linear, blade oblong elliptic, obtuse, oblique. Lip $8 \mathrm{~mm}$ long, $11 \mathrm{~mm}$ wide, sessile, truncate at base, basal part transversely elliptic in outline, lip middle lobe bilobulate, sinus shallow, lobules obliquely elliptic-obovate, margins entire, basal callus glabrous, relatively large, composed of several knob-like projections and additional protuberances on lip lateral lobes. Gynostemium $7 \mathrm{~mm}$ long, ciliate at base, staminodes large, apically overlapping, margins entire.

ETymology. Dedicated to the collector of the type specimen.

HABITAT AND ECOLOGY. It grows on the edges of subandean forest. It was found at 1485-2100 m a.s.l. Flowering in February and November. 
Distribution. Known exclusively from the slopes of the Western Andean Cordillera. So far it was found in the Colombian departments of Antioquia and Valle del Cauca (Fig. 2).

RePresentative SPECIMENS: COLOMBIA. Antioquia: Mpio. Betania, Farallones del Citara, paraje Las Canoas. Quebrada La Bramadora, $5^{\circ} 44^{\prime} \mathrm{N} 76^{\circ} 00^{\prime} \mathrm{W}$, Alt. 2100 m, 12 Nov. 1997, R. Fonnegra, G. Velez \& Grupo Tax. Pl. Vasc. 6641 (MO!); Valle del Cauca: Cordillera Occidental, E slopes. Along highway between Dapa and Loboguerrero at Parque Yotoco, $3^{\circ} 52^{\prime} \mathrm{N} 76^{\circ} 22^{\prime} \mathrm{W}$, Alt. 1485-1550 m, 17 Feb. 1990, T. Croat 70734 (MO!).

Notes. This species resembles $H$. adelaidae, from which it differs by the glabrous callus (vs. callus microscopically hairy at base) consisting of five rows of digitate projections (vs. 5 lamellae). It resembles $H$. rostrans somewhat, but this species produces smaller flowers with a lip lacking protuberances on the lateral lobes, and its gynostemium wings are bilobed.

ACKNOwLEDGEMENTS. The Curator and staff of the Missouri Botanical Garden herbarium are thanked for their kind hospitality and assistance during visits, and for making specimens available on loan. We are grateful to Natalia Olędrzyńska for preparing the illustrations and the anonymous reviewers for their valuable remarks on the manuscript. The research described here was supported by the Polish Ministry of Science and Higher
Education (research grant no. 8124/B/PO1/2011/40) and by the Foundation for Polish Science (Fundacja na rzecz Nauki Polskiej, FNP).

\section{REFERENCES}

Kraenzlin F. 1922. Orchidaceae-Monandrae, Tribus Oncidiinae - Odontoglosseae Pars II. Engelmann, Leipzig.

LiNDLEY J. 1842. Oncidium longifolium (Cebolletae). Edwards's Bot. Reg. 28: 4-5.

LindLey J. 1855. Folia Orchidacea, an enumeration of the known species of Orchids 35: Oncidium. J. Matthews, London.

Lindley J. \& Paxton J. 1850-1851. Paxton's Flower garden. 1. Bradbury and Evans, London.

Senghas K. 1997. 76. Subtribus: Oncidiinae-846. Papperitzia. In: Rudolf Schlechter's, Die Orchideen, ed. 3. 1c(33-36): 2057-2308. Paul Parey, Berlin.

SwARTZ O. 1800. Orchidernes flaegter och arter upstaellde. Kongl. Vetensk. Acad. Nya Handl. 21: 202-254.

SzlachetKo D. L. \& KolanowsKa M. 2015. Reconsideration of Heteranthocidium (Oncidiinae, Orchidaceae) - new species and taxonomic transfers. Plant Syst. Evol. 301: 1793-1805.

Szlachetko D. L. \& Mytnik-Ejsmont J. 2009. Gynostemia Orchidalium IV. Acta Bot. Fenn. 180: 1-313.

SzlachetKo D. L., MytniK-Ejsmont J. \& Romowicz A. 2006. Genera et species Orchidalium. 14. Oncidieae. Polish Bot. J. 51(1): 53-55. 